\title{
ISU POLITIK IDENTITAS DAN DINASTI POLITIK DALAM KAMPANYE PILKADA SERENTAK TAHUN 2020
}

\author{
THE ISSUES OF IDENTITY POLITICS AND POLITICAL DYNASTIES IN THE 2020 \\ SIMULTANEOUS ELECTION CAMPAIGN
}

Aunil Ukhra*, Yana Syafriyana Hijri, Ifan Taufikurrohman

Program Studi Ilmu Pemerintahan, Universitas Muhammadiyah Malang

Jalan Raya Tlogomas Nomor 246 Malang 65144, Indonesia

\section{INFO ARTIKEL}

\section{Riwayat Artikel: \\ Diterima : 07 Oktober 2021 \\ Disetujui : 28 Desember 2021}

\section{Keywords:}

simultaneous elections; political

identity; political dynasty;

elections campaign 2020

\section{Kata Kunci:}

pilkada serentak, politik identitas, dinasti politik, kampanye pilkada tahun 2020

\section{*) Korespondensi:}

E-mail: aunilukhra123@ gmail.com

\begin{abstract}
: this study was intended to explain the phenomenon of identity politics and political dynasties in the holding of simultaneous elections in 2020. The focus of this study was looking at the issue of identity politics and political dynasties in several regions, including Solo, Medan, South Tangerang, and Central Kalimantan, which were case studies of identity politics and political dynasties issue in the 2020 elections. This research used a type of qualitative research with a descriptive approach. Data was obtained through literature studies by looking at previous research based on the same topic and news in the mass media about the issue of identity politics and political dynasties. The study found that identity politics and political dynasties still occurred in some regions, i.e., in Solo, Medan, South Tangerang, and Central Kalimantan. In addition, hate speech, black campaigns, and hoax issues had sprung up with different models through social media and billboards.
\end{abstract}

\begin{abstract}
Abstrak: kajian ini bertujuan menjelaskan fenomena politik identitas dan dinasti politik dalam penyelenggaraan pemilihan umum kepala daerah serentak tahun 2020. Fokus kajian ini ditujukan untuk melihat isu politik identitas dan dinasti politik di beberapa wilayah antara lain Solo, Medan, Tangerang Selatan dan Kalimantan Tengah yang menjadi studi kasus adanya isu politik identitas dan dinasti politik dalam pemilihan umum kepala daerah serentak tahun 2020. Penelitian ini menggunakan pendekatan kualitatif dengan jenis penelitian deskriptif. Data diperoleh melalui studi literatur dengan melihat penelitian terdahulu berdasarkan topik yang sama dan juga pemberitaan di media massa tentang isu politik identitas dan dinasti politik. Hasil penelitian ini menunjukkan bahwa politik identitas dan dinasti politik masih terjadi di beberapa wilayah seperti Solo, Medan, Tangerang Selatan, dan Kalimantan Tengah. Selain itu, ujaran kebencian, kampanye hitam dan isu hoax juga bermunculan dengan model yang berbeda yaitu melalui media sosial dan baliho-baliho.
\end{abstract}

\section{PENDAHULUAN}

Ruang lingkup pemilihan kepala daerah acapkali dipandang sebagai sebuah perwujudan atas demokrasi yang modern di tingkat lokal (Pamungkas \& Triindriasari, 2018). Pemilihan umum yang demokratis harus memenuhi beberapa kriteria antara lain dilaksanakan secara langsung, umum, bebas, rahasia, jujur dan adil (Lestari,
2019). Setiap unsur dari berbagai elemen dapat berpartisipasi baik secara langsung maupun tidak langsung dalam rangka mengeluarkan hasil yang sah dan dapat dipertanggungjawabkan terhadap masyarakat, dengan didasarkan pada pendekatan kontribusi, orientasi, operasional yang menghasilkan pengukuran efektif dari sebuah fenomena demokrasi. Kompetisi untuk 
memperoleh kekuasaan di daerah akan diusahakan secara maksimal melalui kampanye yang masif dan fenomenal.

Strategi propaganda dan agitasi menjadi senjata aktor untuk bisa mendapatkan suara yang maksimal baik dengan cara formal melalui kegiatan kampanye ataupun kegiatan nonformal berbalut politik identitas dan memainkan isu dinasti politik (Dhani, 2019). Secara konsep, identitas sering dimaknai sebagai sebuah citra yang membedakan antara individu yang satu dengan individu lainnya (Katzenstein, 1996). Sedangkan politik identitas didefinisikan sebagai individu atau kelompok masyarakat yang mempunyai kepentingan tertentu dengan menjadikan identitas sebagai tameng dan digunakan dalam konstelasi politik untuk memengaruhi aspirasi dan kebijakan publik (Anam, 2019). Identitas yang meliputi agama, suku, ras, bahasa dan lain sebagainya digunakan sebagai alat untuk menunjang kegiatan politik.

Fenomena politik identitas adalah isu dominan untuk negara demokrasi dengan keadaan dan kondisi masyarakat yang heterogen (Ardipandanto, 2020). Kuatnya pengaruh politik identitas di ranah lokal dikhawatirkan dapat menimbulkan segregasi dalam kehidupan sosial masyarakat yang berkelanjutan (Dauly, Kusmanto, \& Kadir, 2019). Politik identitas sejauh pelaksanaan pemilihan umum baik di tingkat nasional maupun lokal menjadi isu yang ampuh untuk merobohkan pertahanan lawan politik. Unsur-unsur tersebut antara lain suku, agama, ras, dan antar golongan (Dauly, Kusmanto, \& Kadir, 2019). Penggunaan politik identitas dapat terwujud dengan cara yang berbedabeda (Faridiany, Kusmanto, \& Warjio, 2019). Kampanye memungkinkan setiap kandidat dan partisipan mempropagandakan bentuk-bentuk yang unik.

Masifnya penggunaan politik identitas terjadi dalam pemilihan umum hampir di semua sektor baik pemilihan presiden, anggota legislatif maupun eksekutif di daerah. Keadaan ini diperkeruh sejak pemilihan gubernur DKI Jakarta pada tahun 2017 (Lestari, 2019). Isu politik identitas yang sangat fenomenal terjadi dalam perhelatan pemilihan kepala daerah DKI Jakarta pada tahun 2017. Politik identitas yang digulirkan adalah suku dan agama. Hal tersebut bermula ketika Basuki Tjahaja Purnama (Ahok) yang berasal dari kalangan nonmuslim dituduh menistakan agama akibat mengutip Surat Al-Mai'dah Ayat 51 dalam kunjunganya ke Kepulauan Seribu pada 30 September 2016 (Lestari, 2019). Isu tersebut dijadikan sebagai boomerang untuk kandidat Ahok-Djarot yang kemudian melahirkan aksi berjilid-jilid. Propaganda tersebut menimbulkan jurang pemisah yang berkepanjangan antara pendukungnya sehingga berpengaruh pada sentimen anti-China atau asing di kalangan masyarakat.

Penggunaan politik identitas memberikan dampak buruk terhadap kehidupan demokrasi apalagi isu SARA telah mendarah daging bahkan sejak Indonesia belum merdeka (Lestari, 2019). Kemenangan kandidat Anies Baswedan dan Sandiaga Salahuddin Uno yang mendapatkan 3.240 .332 atau $57,95 \%$ di putaran kedua, padahal di putaran pertama mendapat suara 2.197.333 atau 39,95\% sedangkan pasangan Ahok-Djarot 2.364.577 atau 42,99\% lebih unggul. Isu politik identitas pun pada kenyataannya berlanjut pada pemilihan umum kepala daerah (pilkada) serentak di beberapa daerah pada tahun 2018, pemilihan presiden tahun 2019 dan pilkada serentak tahun 2020.

Identitas politik yang digunakan oleh kandidat melalui simbol non-verbal seperti tagline dan sejenisnya membangun kedekatan emosional dengan pemilih (Slamet, 2019). Pasangan calon gubernur yang menggunakan strategi tersebut antara lain Deddy Mizwar, Ridwan Kamil, Sudrajat, dan Tubagus Hasanuddin. Isu agama tidak digaungkan dalam fenomena politik di Jawa Barat karena dari pasangan calon memiliki kesamaan perihal agama sehingga disimplifikasi menjadi simbol-simbol tertentu. Penelitian Pamungkas dan Triindriasari (2018) membahas politik identitas pada sudut pandang identitas etnik, hal yang lebih dominan terjadi di Papua dalam pilkada serentak tahun 2018. Hasil penelitian menunjukkan bahwa isu tersebut lebih sarat akan kepentingan elit-elit tertentu yang ingin agar kepentingannya diakomodasi dengan tujuan utamanya adalah penggunaan sumber daya baik alam maupun manusianya. Dampaknya adalah isu-isu identitas kepapuaan menjadi tidak optimal.

Pengkajian politik identitas dari sudut pandang agama juga dilakukan. Kajian tersebut lebih membahas tentang eksklusifitas 
agama Islam yang berpengaruh terhadap jalannya demokrasi di Indonesia (Anam, 2019). Meningkatnya fenomena politik identitas ini membuka jurang antara agama di masyarakat Indonesia yang heterogen. Beberapa tahun terakhir, populisme Islam yang terdominasi dalam politik identitas sangat berpengaruh baik dari kalangan agamawan, politikus sampai ke gerakan akar rumput. Ada pula dikotomi strategi identitas untuk mendapatkan suara masyarakat yaitu melalui pendekatan politik dan pendekatan budaya (Dauly, Kusmanto, \& Kadir, 2019). Pendekatan politik dilakukan oleh pasangan Edy Rahmayadi dan Musa Rajek Shah (ERAMAS) dengan melakukan pendekatan terhadap tokoh adat dan agama, sedangkan pasangan Djarot Saiful Hidayat dan Sihar Sitorus (DJOSS) melakukan pendekatan budaya.

Pola pendekatan yang berbeda antara dua pasangan calon tersebut membentuk sebuah sentimen di masyarakat. Strategi tersebut dianggap dapat memberikan sumbangsih pada keterpihakan mayoritas. Cara yang dilakukan kedua pasangan calon gubernur tersebut adalah dengan menggunakan iklan politik berbasis identitas (Faridiany, Kusmanto, \& Warjio, 2019). Isu lainnya adalah dengan menamakan diri sebagai putra daerah untuk mendekatkan emosionalitasnya dengan masyarakat. Fenomena lain yang dominan dalam pergelaran pilkada serentak tahun 2020 adalah isu dinasti politik.

Secara konseptual dinasti politik merupakan sistem reproduksi kepemimpinan yang mengandalkan hubungan familisme atau kekerabatan dengan elit-elit tertentu (Gunanto, 2020). Beberapa elit politik di tingkat pusat semakin menunjukkan dinasti politik melalui reproduksi kepemimpinan baik dalam bidang partai politik maupun secara langsung sebagai pejabat publik (Ichsan dkk., 2020). Isu dinasti politik muncul bersamaan dengan isu politik identitas di Pilkada serentak tahun 2020 dengan adanya pencalonan dari entitas familisme dalam konstelasi pemilihan umum. Kecenderungan untuk membangun dinasti politik ini tidak hanya dilakukan di tataran partai atau di pemerintahan pusat tetapi sampai ke tataran pemerintahan daerah.

Berdasarkan berbagai fenomena yang telah dipaparkan di atas maka peneliti mengkaji lebih jauh tentang fenomena politik identitas dan politik dinasti yang terjadi di pilkada serentak tahun 2020 dengan mengkaji fenomena tersebut di beberapa daerah antara lain Solo, Tangerang Selatan, Kalimantan Tengah dan Medan. Pola pengkajian didasarkan pada sistem, cara, dan strategi yang dilakukan sehubungan dengan politik identitas dan dinasti politik. Hasil kajian dan pembahasan ini diharapkan dapat memberikan gambaran terhadap politik identitas dan politik dinasti dalam konteks demokrasi untuk Indonesia saat ini dan ke depan.

\section{METODE}

Metode yang digunakan dalam penelitian ini adalah metode kualitatif. Penelitian ini berusaha menganalisis tentang politik identitas dan isu dinasti politik dalam pelaksanaan pilkada serentak tahun 2020. Pendekatan metode kualitatif dalam penelitian ini dilaksanakan dalam bentuk deskripsi. Penelitian ini mengkaji secara literatur tentang fenomena isu politik identitas dan isu dinasti politik dalam pilkada serentak tahun 2020 dari berbagai media dan juga sumber tertulis lainnya untuk melengkapi ulasan pembahasan peneliti. Teknik analisis data diolah berdasarkan pada fakta yang ditemukan melalui media sosial, jurnal penelitian terdahulu dan juga literatur sehubungan dengan penyebaran isu politik dinasti dan politik identitas di empat wilayah antara lain Solo, Kalimantan Tengah, Medan, dan Tangerang Selatan.

\section{HASIL DAN PEMBAHASAN}

\section{Politik Identitas pada Pemilihan Umum Kepala Daerah Serentak 2020}

Sistem politik demokrasi merupakan salah satu bentuk pelaksanaan kedaulatan rakyat di Indonesia. Wujud keterlibatan rakyat adalah melalui pemilihan umum yang dilaksanakan secara periodik. Pemilihan umum yang dilaksanakan di Indonesia terbagi menjadi pemilihan untuk memilih legislatif dan pemilihan untuk memilih eksekutif. Rakyat memiliki kekuasaan untuk menentukan pemimpin yang kemudian akan diamanahi untuk menjalankan pemerintahan dalam sebuah sistem demokrasi langsung. Pilkada serentak menjadi salah satu model pelaksanaan demokrasi di Indonesia yang dijadikan sebagai keran pergantian kepemimpinan dari satu entitas ke entitas yang lain.

Pilkada harus dilakukan dalam kondisi apapun, termasuk di masa pandemi. Pilkada adalah gerbang rotasi kepemimpinan di daerah yang merupakan prasyarat dari sebuah negara 
demokrasi. Maka dari itu, meskipun pandemi COVID-19 melanda dunia dan berdampak pada Indonesia, pilkada serentak tetap dilaksanakan pada tanggal 9 Desember 2020. Keputusan pemerintah untuk tetap menjalankan pilkada serentak ini pada awalnya menimbulkan pro dan kontra. Penyebabnya adalah di saat bersamaan pandemi COVID-19 masih massif melanda Indonesia sehingga pelaksanaan pilkada serentak pun diundur yang seharusnya dilaksanakan pada 23 September 2020 ditunda ke 9 Desember 2020. Pada 9 Desember 2020, beberapa wilayah di Indonesia menjalankan pemilihan kepada daerah baik di tingkat provinsi maupun kabupaten/kota.

Alasan mendasar pilkada serentak dilaksanakan pada tahun 2020 tanpa menunggu tahun 2021 adalah agar jalannya pemerintahan lebih optimal karena kepemimpinan pelaksana tugas/penjabat (Plt./PJ) secara definitif memiliki kewenangan yang terbatas (Farisa, 2020). Pertimbangan lain pelaksanaan pilkada tetap di tahun 2020 adalah dari sisi anggaran. Selain itu, secara konstitusional pergantian pemimpin harus dijalankan lima tahun sekali. Pilkada serentak di tengah pandemi COVID-19 ini memerlukan perlakuan khusus karena seiring dengan diberlakukan pembatasan kegiatan masyarakat di beberapa kabupaten dan kota di Indonesia (Marisa, Pornauli, Indra, \& Aurora, 2020). Pilkada serentak tahun 2020 terlaksana di 270 wilayah di Indonesia, meliputi 9 provinsi, 224 kabupaten, dan 37 kota (Aida, 2020). Faktor utama pilkada serentak tahun 2020 tetap harus dilaksanakan walaupun berubah dari jadwal biasa adalah agar kepala daerah dapat bekerja lebih optimal untuk dapat dengan segera mengatasi pandemi COVID-19 di Indonesia

Regulasi tentang pilkada serentak tahun 2020 pada dasarnya telah tertuang dalam Undang-Undang Nomor 10 Tahun 2016 Pasal 201 ayat 6 yang berbunyi "Pemungutan suara serentak Gubernur dan Wakil Gubernur, Bupati dan Wakil Bupati, serta Walikota dan Wakil Walikota hasil pemilihan tahun 2015 dilaksanakan pada bulan September tahun 2020" (Ristyawati, 2020), sedangkan pengaturan tentang tata laksana penyelenggaraan pilkada serentak di tengah pandemi COVID-19 diatur dalam Peraturan Pemerintah Pengganti Undang-Undang (PERPPU) Nomor 2 Tahun 2020 tentang Pilkada. Penyelenggaraan kampanye dalam pilkada serentak tahun 2020 dilakukan oleh kandidat kepada para simpatisan. Penyelenggaraan kampanye harus menyesuaikan regulasi yang ditentukan sebagai akibat dari pandemi COVID-19. Pembatasan sosial di wilayah kabupaten maupun kota menutup peluang untuk diadakannya kampanye secara akbar.

Peraturan Komisi Pemilihan Umum (PKPU) 10/2020 yang tertuang dalam Pasal 58 sampai pasal 60 menjelaskan bahwa pelaksanaan kampanye hanya dilakukan secara terbatas dan wajib menerapkan protokol kesehatan yang sangat ketat (Prabowo, 2020). Media kampanye pada akhirnya termimikri dalam berbagai bentuk salah satunya menggunakan media sosial. Media sosial menjadi cara yang dianggap efektif sebagai media kampanye di tengah pembatasan. Masifnya penyebaran kampanye dan pengenalan kandidat melalui media sosial, berdampak terhadap beberapa kejahatan siber dan maraknya isu politik identitas yang ditujukan kepada beberapa pasangan. Isu tersebut menjadi penampakan umum dalam penyelenggaraan pemilihan serentak tahun 2020 .

Fenomena politik identitas dapat ditelusuri sejak diberlakukannya undang-undang Nomor 32 Tahun 2004 tentang Pemerintah Daerah yang menetapkan bahwa masyarakat di daerah dapat memilih secara langsung pemimpinnya (Lestari, 2019). Pembentukan identitas tersebut didasarkan pada kesadaran kolektif masyarakat yaitu munculnya sentimen berdasarkan kesamaan yang dimiliki oleh simpatisan dengan kandidat yang didukungnya. Timbulnya spesifikasi tersebut memberikan kategorisasi didasarkan pada perbedaan yang dimiliki dengan objek tertentu. Nama lain dari realitas tersebut adalah biopolitik, politik didasarkan pada perbedaan (Dhani, 2019). Faktor pendorong terbentuknya identitas yang kemudian bermuara dalam konstelasi politik tanah air adalah adanya perasaan ketidakadilan yang dirasakan oleh individu atau kelompok masyarakat.

Ketidakadilan yang terjadi sebagian besar ditimbulkan oleh adanya polarisasi berdasarkan status sosial seperti oligarki, latar belakang pendidikan dan kurangnya rasa egalitariarisme (Jung \& Mittal, 2020). Posisi tersebut biasanya terdampak oleh tidak masuknya individu atau kelompok tertentu atau dengan kata lain terpinggirkan dalam status sosialnya (Ayu, 2020). Upaya tersebut disebabkan oleh perasaan 
termarjinalisasi, mengalami penindasan, terpinggirkan secara sosial, ekonomi, dan budaya dalam kurun waktu yang lama (Mahpudin, 2019). Ada tujuh wilayah dengan tingkat diagnosis terhadap isu SARA dengan tingkat kerawanan yang tinggi antara lain Kota Depok, Kabupaten Halmahera Timur dan Kabupaten Solok, 18 daerah dengan tingkat kerawanan sedang dan 236 dengan tingkat kerawanan rendah dari berbagai daerah yang melaksanakan pilkada serentak (Balitbang HAM, 2020). Tingkat kerawanan tersebut terbentuk oleh beberapa indikator seperti menguatnya politisasi isu suku, agama, ras, antar golongan dan politisasi identitas. Kecenderungan politisasi atas isu-isu tersebut berpengaruh pada kategorisasi tingkat kerawanan yang ada di setiap wilayah.

Pergeseran isu politik identitas telah termodifikasi dalam postingan dan cuitan di media sosial yang penuh dengan ujaran kebencian dan gambar-gambar berkaitan dengan SARA Kartika (2020). Isu identitas semakin mengakar di kalangan masyarakat Indonesia sehingga dalam bentuk dan kondisi apapun isu identitas masih menjadi jualan yang berpengaruh. Perubahan peradigma masyarakat dapat dipengaruhi oleh propaganda dari yang memiliki status yang lebih tinggi seperti presiden atau entitas lain (Hornsey, Finlayson, Chatwood, \& Begeny, 2020). Resesi demokrasi kian tampak dengan penggulingan isu identitas karena dianggap murah dan mampu mengendalikan emosi massa melalui narasi-narasi yang dibuat. Kemunduran dari pemilihan umum sebelumnya telah memberikan dampak yang sangat buruk bagi konstelasi politik setelahnya dimana jualan politik identitas menjadi satu hal yang tidak luput karena dianggap sebagai strategi yang menarik minat massa. Di lain sisi, isu identitas yang digulirkan cenderung dipaksakan untuk diikuti oleh massa baik yang merupakan pendukung maupun yang bukan (Drozdzewski \& Matusz, 2021). Oleh karena itu, mengakarnya isu identitas dalam mayoritas masyarakat tidak dapat dikesampingkan peran dari elit-elit massa yang berusaha membaca realitas ini sebagai satu peluang politik bahkan merambah sampai ke faktor ekonomi, budaya dan lainnya. Pentingnya etika politik untuk menvalidasi isu-isu yang berkembang perlu ditingkatkan sebagai bentuk pengetahuan politik masyarakat (Vakil, 2018)

\section{Isu Politik Identitas dalam Perhelatan Pilkada Kalimantan Tengah}

Pilkada serentak yang dilaksanakan di Kalimantan Tengah melibatkan dua pasangan calon antara lain nomor urut satu adalah Ir. Ben Brahim S. Bahat, M.M., M.T-Dr. Ujang Iskandar, ST., M.Si dan nomor urut dua H. Sugianto Sabran-H. Edy Pratowo, S. Sos. M.M. Pasangan nomor urut satu diusung oleh beberapa partai antara lain Partai Demokrat, Partai Gerindra dan Partai Hanura sedangkan pasangan calon nomor urut dua diusung oleh Partai Nasdem, PDIP, PKS, PKB, Perindo, PPP, Partai Golkar, dan PAN. Badan Pengawas Pemilihan Umum (Bawaslu) Kalimantan Tengah dalam regulasinya mengatur bahwa kampanye di tengah pandemi COVID-19 ini hanya dapat dilakukan secara tertutup dan maksimal yang mengikuti adalah 50 orang. Dengan demikian, pelaksanaan kampanye yang dilakukan secara umum sangat dilarang (Mulang, 2020). Perbedaan pola kampanye ini beralih pada kampanye yang dilakukan melalui media sosial.

Ironisnya, isu-isu yang digaungkan selama masa kampanye pilgub Kalimantan Tengah melalui media sosial berupa ujaran kebencian dan fitnah. Salah satu contohnya adalah ujaran kebencian yang terhadap pasangan Ben-Ujang dengan sebutan "boneka" karena dianggap tidak serius mencalonkan diri sebagai kandidat pilgub (Lerang, 2020). Usaha pengguliran narasi tersebut dapat memberikan pengaruh terhadap preferensi pemilih. Selain itu, pengalihan isu di media sosial yang mengungkit masa lalu salah satu kandidat juga menyebabkan terjadinya kesalahpahaman di antara masyarakat seperti isu korupsi (Nata, 2021). Masifnya isu-isu yang beredar di media sosial menjadi sarana yang dapat menimbulkan konflik di tengah masyarakat. Oleh karena itu, pola kontrol yang sangat minim akan mempengaruhi pendapat publik sehingga dengan sendirinya ruang pemisah antara pendukung satu kandidat dengan kandidat lainnya akan sangat terbuka lebar.

Sisipan isu dinasti politik dan berbagai isu lain memberikan pengaruh yang cukup signifikan terhadap pengetahuan para pemilih (Sandi, 2020). Perluasan isu-isu yang berkaitan dengan pilkada Kalimantan Tengah seperti ujaran kebencian dan hoax yang banyak ditemukan di media sosial dapat diantisipasi dengan baik oleh aparat penegak hukum sehingga yang kedapatan 
menyebarkan hoax dan ujaran kebencian ataupun mengumbar tentang isu identitas dapat dengan segera ditindak (Trisnawati, 2020). Hal ini penting untuk dilakukan agar konflik-konflik yang bersumber dari isu identitas tidak meluas. Seyogyanya, setiap daerah juga memiliki antisipasi terkait dengan isu identitas tersebut.

\section{Isu Politik Identitas dalam Perhelatan Pilkada Medan}

Pilkada serentak tahun 2020 juga melibatkan Kota Medan dalam konstelasi demokrasi Indonesia. Terdapat dua pasangan kandidat calon yang akan menduduki jabatan sebagai walikota dan wakil walikota Medan antara lain Bobby Afif Nasution-Aulia Rachman yang diusung oleh Partai Gerindra, Partai Golkar, Partai NasDem, PDIP, PSI, PAN, Hanura dan PPP yang memiliki 39 kursi di legislatif daerah. Sedangkan kandidat lainnya adalah Akhyar Nasution-Salman Alfarisi diusung oleh Partai Demokrat dan PKS. Dalam proses kampanye, suasana perpolitikan di Medan bermunculan beberapa isu yang berkaitan dengan identitas. Isu identitas paling banyak menyerang pasangan Bobby Afif Nasution-Aulia Rachman. Salah satu isu yang yang berkembang dalam perdebatan di media sosial berkaitan dengan Bobby Nasution karena ia adalah menantu dari Presiden Joko Widodo. Ia dinilai merupakan bagian dari bangunan dinasti politik Presiden Joko Widodo. Selain isu dinasti politik, beberapa ujaran provokatif banyak bertebaran di media sosial yang mengatakan bahwa Bobby Nasution masih memiliki pengalaman yang minim dan belum terlalu memahami Kota Medan.

Bobby dianggap banyak menghabiskan waktu di kota lain sehingga tidak pantas untuk menjadi pemimpin di Kota Medan. Selain itu, salah satu isu identitas yang timbul adalah isu agama yang dialirkan saat kampanye pilkada di Medan dengan menggunakan salah satu tokoh agama untuk mengkampanyekan memilih pasangan Akhyar Nasution-Salman Alfarisi (AMAN) (Gandeng UAS, Kubu Bobby Tuding Akhyar Politik Identitas, 2021). Narasi yang digaungkan oleh tokoh agama tersebut adalah agar masyarakat dapat memilih pasangan AMAN yang dapat merepresentasikan Islam. Pasangan tersebut diharapkan datang mengetuk dari pintu ke pintu untuk dapat menunjukkan kehadiran mereka di tengah masyarakat. Selain itu juga, diharapkan agar pasangan AMAN ketika menjabat dapat lebih membantu pembangunan masjid, kaum duafa, dan membantu umat.

Secara sosial, kampanye dengan menggunakan embel-embel agama memang akan menimbulkan kontra persepsi di masyarakat karena secara komposisi, Kota Medan terdiri atas masyarakat yang heterogen. Hal tersebut akan memberikan dampak buruk jika isu identitas masih diperjualbelikan dalam pilkada serentak atau pesta demokrasi sebagai langkah untuk mendapatkan simpati dari pemilih.

\section{Dinasti Politik di Indonesia}

Politik dinasti merupakan strategi politik oligarki untuk dapat melanggengkan kekuasaan sedangkan dinasti politik adalah reproduksi kekuasaan dengan mengandalkan kekuatan familisme atau kekerabatan (Gunanto, 2020). Salah satu isu dinasti politik yang menjadi sorotan publik beberapa tahun lalu adalah kasus Gubernur Banten Ratu Atut yang membangun dinasti politik melibatkan saudara, suami, ipar, mertua, ibu tiri, hingga anak-anaknya (Effendi, 2018). Hal tersebut mirip dengan sistem monarki yang mengandalkan garis keturunan. Hanya yang membedakan adalah dalam sistem demokrasi harus dilalui dengan pemilihan umum. Namun, strategi politik didasarkan pada ikatan familisme dan kekerabatan yang akan dengan sangat mudah memanipulasi suara rakyat.

Apabila dijabarkan secara detail, terdapat begitu banyak contoh yang dapat dijadikan sebagai preseden buruk maraknya dinasti politik di Indonesia. Bahkan yang lebih masif terjadi di tingkat lokal baik di tingkat provinsi maupun di tingkat kabupaten/kota. Jika ditarik secara historis, embrio dinasti politik di Indonesia dapat ditelusuri sejak zaman Presiden Soekarno yang tercermin melalui diri Megawati Soekarnoputri, Sukmawati, dan Guruh Soekarno. Bahkan kini, Putri dari Megawati Soekarnoputri, Puan Maharani melanjutkan jejak dinasti sampai ke tahap sebagai Ketua DPR RI yang juga pernah sebagai menteri, anggota DPR dan sebagai elit di partai politik. Demikian pula presidenpresiden setelahnya seperti KH. Abdurrahman Wahid, Soeharto melalui keluarga cendanannya, Susilo Bambang Yudhoyono (SBY) yang bahkan sekarang anaknya memimpin di Partai Demokrat. Kini Presiden Joko Widodo pun kembali menjadi perbincangan karena dinilai terimbas virus dinasti politik melalui pencalonan Gibran Rakabuming 
Raka, menjadi calon walikota Solo dan terpilih. Selain itu juga menantunya Bobby Nasution juga terpilih menjadi walikota Medan.

Kokohnya dinasti politik oleh elit lokal maupun daerah berdampak terhadap model demokrasi yang diterapkan. Kesempatan untuk masyarakat kelas menengah dan masyarakat kecil untuk memimpin menjadi sangat minim karena hampir di setiap sektor pencalonan didominasi oleh dinasti politik. Hal tersebut menimbulkan pergolakan di akar rumput pemilih dan juga di tingkat atas yang memiliki kepentingan. Banyak pro kontra yang terjadi tentang pencalonan kandidat yang memiliki kedekatan dengan elit. Masalah ini menimbulkan kritik dan juga isu- isu miring yang banyak ditemukan di media sosial. Ditambah lagi polarisasi ini merupakan dampak dari pesta demokrasi tahun 2019 yang sarat akan politik identitas. Umpan baliknya adalah banyak masyarakat yang menggunakan media sosial sebagai sarana untuk menggiring isu SARA. Data terakhir menunjukkan bahwa jumlah 130 juta penduduk Indonesia merupakan pengguna Facebook dan merupakan urutan keempat pengguna Facebook terbanyak di dunia, 50 juta orang pengguna Twitter dan 45 juta orang pengguna Instagram (Wartika, 2020). Pilkada serentak 2020 pun tidak luput dari adanya dinasti politik yang masif dalam kampanye di beberapa daerah.

Tabel 1. Keluarga Presiden Republik Indonesia yang Menjadi pejabat Publik

\begin{tabular}{|c|c|c|c|c|}
\hline No & Presiden & Tahun & Keluarga yang menjadi Pejabat Publik & Ket \\
\hline \multirow{2}{*}{1} & \multirow{2}{*}{ Soekarno } & \multirow{2}{*}{$1945-1967$} & - Megawati (Presiden 5) & Anak \\
\hline & & & - Ibu Tutut (Mensos 1998) & Anak \\
\hline \multirow{2}{*}{2} & \multirow{2}{*}{ Soeharto } & \multirow{2}{*}{$1967-1998$} & - Titiek Soeharto (Anggota DPR RI 2014-2018) & Anak \\
\hline & & & - Tommy Soeharto (Anggota DPR RI 1992-1998) & Anak \\
\hline 3 & Habibie & 1999-1999 & - & - \\
\hline 4 & Gusdur & $1999-2001$ & - Yenny Wahid (Stafsus Presiden Gusdur) & Anak \\
\hline \multirow{2}{*}{5} & \multirow{2}{*}{ Megawati } & \multirow{2}{*}{$2001-2004$} & - Puan Maharani (Ketua DPR RI 2019-2004) & Anak \\
\hline & & & - Alm. Taufik Kiemas (MPR RI 2019-2004) & Suami \\
\hline \multirow{2}{*}{6} & \multirow{2}{*}{$\begin{array}{l}\text { Susilo Bambang } \\
\text { Yudhoyono }\end{array}$} & \multirow{2}{*}{$2004-2014$} & - Edhie Baskoro (Anggota DPR RI 2019-2004) & Anak \\
\hline & & & - Agus Yudhoyono (Ketua Partai Demokrat 2020-2025) & Anak \\
\hline \multirow{2}{*}{7} & \multirow{2}{*}{ Jokowi } & \multirow{2}{*}{ 2014-Sekarang } & - Gibran R. Raka (Walikota Solo 2021-Sekarang) & Anak \\
\hline & & & - Boby Nasution (Walikota Medan (2021- sekarang) & Menantu \\
\hline
\end{tabular}

Tabel 2. Dinasti Politik Lokal di Pilkada Serentak 2020

\begin{tabular}{lll}
\hline No & Kandidat & Familisme \\
\hline 1. & Gibran Rakabuming Raka-Teguh Prakosa & Gibran, Anak Presiden Joko Widodo \\
\hline 2. & Bobby Afif Nasution-Aulia Rachman & Bobby, Menantu Joko Widodo \\
\hline 3. & Benyamin Davnie-Pilar Saga Ichsan & Pilar, anak Ratu Tatu Chasanah (Bupati Serang) \\
\hline 4. & Rezita Melyani-Junaidi Rachmat & Rezita, istri Bupati Indragiri Hulu Yopi Arianto \\
\hline 5. & Hanindhito Himawan Pramana-Dewi Mariya Ulfa & Hanindhito, anak Sekretaris Kabinet Pramono Agung \\
\hline 6. & Eva Dwiana-Deddy Amarullah & Eva, istri Wali Kota Bandar Lampung Herman HN \\
\hline 7. & Kustini Sri Purnomo-Danang Maharsa & Kustini, istri Bupati Sleman Sri Purnomo \\
\hline 8. & Ansar Ahmad-Marlin Agustina & Marlin, istri Wali Kota Batam Muhammad Rudi \\
\hline 9. & Ipuk Fiestiandani Azwar Anas-Sugirah & Ipuk, istri Bupati Banyuwangi Azwar Anas \\
\hline 10. & Ratu Tatu Chasanah-Pandji Tirtayasa & Tatu, adik mantan Gubernur Banten Ratu Atut Chosiyah \\
\hline
\end{tabular}

(Sumber: Bayu, 2020) 


\section{Isu Dinasti Politik dalam Perhelatan Pilkada Solo}

Kota Solo merupakan sebuah kota otonom dengan nama lain Kota Surakarta yang masuk dalam administrasi Provinsi Jawa Tengah. Penyelenggaraan pilkada serentak pada 9 Desember 2020 memunculkan dua pasangan calon antara lain Gibran Rakabuming RakaTeguh Prakosa dan Bagyo Wahyono-FX Supardjo berdasarkan keputusan KPU Solo nomor: 77/ PL.02.3-Kpt/3372/KPU-Kot/IX/2020 (Zamani, 2020). Pasangan Gibran Rakabuming Raka-Teguh Prakosa maju melalui jalur Partai Demokrasi Indonesia Perjuangan (PDIP) dengan komposisi 30 kursi di legislatif sedangkan pasangan Bagyo Wahyono-FX Supardjo maju melalui jalur independen dengan dukungan organisasi masyarakat.

Pasangan Gibran Rakabuming RakaTeguh Prakosa menggunakan pola kampanye online dengan alat yang didesain khusus untuk ditempatkan di tempat umum sedangkan pasangan Bagyo Wahyono-FX Supardjo menggunakan video call sebagai metode kampanyenya. Selain itu pola kampanye lain juga ditempuh oleh masing-masing pasangan calon ini salah satunya dengan mendatangi rumah warga secara langsung untuk menjelaskan visi, misi dan program kerja secara langsung untuk mengurangi kerumunan warga (Kurniawan, 2020). Metode kampanye ini dijadikan alternatif untuk mengurangi interaksi dan meminimalisir berkumpulnya masyarakat. Penggunaan media sosial menjadi salah satu cara yang dapat diambil untuk mengkampanyekan kandidat masing-masing. Metode ini secara langsung memberikan hal positif kepada pasangan calon karena tidak membutuhkan biaya yang mahal. Catatan media menunjukkan bahwa modal kampanye dari pasangan Gibran Rakabuming Raka-Teguh Prakosa mencapai Rp3.215.119.818,00 sedangkan pasangan Bagyo Wahyono-FX Supardjo menghabiskan Rp110.217.386,00 (Wibowo, 2020).

Seiring dengan pelaksanaan kampanye yang lebih dominan dilakukan melalui media sosial, isu negatif juga bermunculan yaitu isu dinasti politik. Isu ini kembali digaungkan dalam pilkada Solo karena salah satu calonnya yaitu Gibran Rakabuming Raka, anak kandung Presiden Ir. Joko Widodo. Isu dinasti politik bertebaran di media sosial yang secara tidak langsung berpengaruh terhadap elektabilitas dari pasangan Gibran. Beberapa ahli menilai bahwa munculnya isu dinasti politik yang disodorkan pada publik tidak terlepas dari PDIP yang mengusulkan Gibran Rakabuming Raka sebagai calon walikota Solo, padahal terdapat banyak kader lama yang lebih berpengalaman yang dapat dijadikan sebagai calon yang akan maju di pilkada serentak Kota Solo (Pradita \& Sicca, 2020). Namun, kehadiran Gibran dengan backingan politik yang kuat mengubah arah politik di Solo.

Isu dinasti politik ini menimbulkan beberapa spekulasi yang kemudian beranggapan bahwa dicalonkannya Gibran Rakabuming Raka dari PDIP tidak luput dari campur tangan presiden yang juga adalah kader PDIP. Artinya sentimen publik makin diarahkan untuk sekiranya menganggap bahwasanya campur tangan elit politik turut berperan dalam proses pencalonan ini. Hal ini mengakibatkan peta perpolitikan di Solo menjadi terpecah. Ujaran-ujaran yang memprovokasi timbul dari banyaknya komentar bahkan postingan dari oknum-oknum yang berusaha menguatkan isu dinasti politik dengan dalih Gibran Rakabuming Raka mencuri kesempatan selagi ayahnya menjabat sebagai presiden. Keterlibatan tersebut semakin diperkuat oleh turunnya Megawati Soekarnoputri yang merupakan ketua umum PDIP untuk berkampanye secara langsung dalam usaha memenangkan Gibran dan pasangan. Berbagai ujaran kebencian juga dilontarkan untuk menilai bahwa persaingan politik di Solo ibarat persaingan antara yang mampu dan tidak mampu.

Bentuk kampanye dan total dana kampanye yang dikeluarkan dapat juga menjadi bukti bahwa perbedaan dari sisi ekonomi dan latar belakang sangat mendukung dalil tersebut. Selain itu, adanya kandidat yang maju melalui jalur independen dianggap sebagai kandidat hasil settingan. Walaupun pada akhirnya isu politik dinasti itu tidak dapat mempengaruhi perolehan suara Gibran Rakabuming Raka dan pasangannya yang tetap memenangi pilkada Kota Solo. Dukungan dari elit-elit politik di tingkat lokal Kota Solo dan juga di tingkat pusat melalui PDIP dan presiden sangat berpengaruh terhadap arah politik di Kota Solo (Suryatwan, 2020). Kegelisahan publik tertuju pada usaha Presiden Jokowi untuk meneruskan dinasti melalui jalur walikota Solo. Secara regulasi memang tidak diatur secara detail tentang adanya 
larangan untuk sistem pencalonan kerabat atau family terdekat pejabat publik yang sedang menduduki posisi penting. Berbeda dengan yang terjadi di Provinsi Banten ketika masa kepemimpinan Ratu Atut yang secara jelas menjalankan dinasti politik. Walaupun isu dinasti politik disebarkan melalui media sosial sebagai upaya untuk menurunkan elektabilitas Gibran dan pasangannya, hasil pemilihan umum tetap dimenangkan oleh kedua pasangan ini.

Terlepas dari hasil pemilu tersebut, majunya Gibran dalam pemilihan Walikota Solo menambah daftar panjangnya riwayat dinasti politik di Indonesia. Perspektif masyarakat menjadi terganggu dengan adanya regenerasi kekuasaan yang monoton oleh keluarga elit politik saja. Pasalnya, kemunculan Gibran yang memutuskan berkecimpung di dunia politik dinilai terlalu ambisius. Karena, latar belakang politik Gibran yang dianggap masih prematur. Akibat adanya kekuatan politik yang sangat signifikan, kader-kader PDIP termasuk petahana F. X Suparjo akhirnya memutuskan untuk tidak mencalonkan diri karena "kalah secara politik" (Suryatwan, 2020). Preseden ini juga menggurita di tingkat lokal dimana kehadiran pemimpin yang prematur secara pengalaman politik berkembang sedemikian rupa karena adanya dukungan dari familisme dan kekerabatan yang sangat kuat. Di satu sisi memberikan keuntungan secara politis tetapi di lain pihak berpengaruh terhadap kelompok masyarakat umum yang juga ingin memimpin baik di tingkat lokal maupun pusat entah sebagai eksekutif maupun sebagai legislatif.

\section{Isu Dinasti Politik dalam Perhelatan Pilkada Tangerang Selatan}

Tangerang Selatan, secara administrasi termasuk dalam Provinsi Banten bagian timur. Pilkada serentak di Tangerang Selatan diikuti oleh tiga pasangan calon antara lain pasangan dengan nomor urut satu yaitu H. MuhammadRahayu Saraswati Djojohadikusumo (Sara) yang diusung oleh Partai Gerindra, PDIP, PKS, PAN, dan Hanura, dengan total 23 kursi di parlemen Tangerang Selatan, pasangan nomor urut dua yaitu Siti Nurazizah-Ruhamaben yang didukung oleh Partai Keadilan Sejahtera (PKS), Partai Demokrat dan Partai Kebangkitan Bangsa (PKB) dengan komposisi 17 kursi legislatif, dan pasangan nomor urut tiga Benyamin Davnie-Pilar Saga Ichsan yang diusung oleh Partai Golkar dengan dukungan tambahan oleh PPP, PBB dan Partai Gelora. Selain partai, latar belakang keluarga juga memberikan stimulus yang besar dalam setiap pencalonan tersebut (Arbi, 2020).

Salah satu pasangan calon yang menonjol dan banyak dijadikan isu dinasti politik adalah Rahayu Saraswati Djojohadikusumo yang merupakan keponakan dari Menteri Pertahanan Prabowo Subianto yang sekaligus menjadi kader dari Partai Gerindra. Keterlibatan perempuan dalam konstelasi politik memengaruhi diferensiasi pemilih. Dampak dari hal tersebut mengakibatkan alternatif pemilih perempuan untuk menentukan pasangan calon yang akan dipilih menjadi lebih terbuka (Dulani, Rakner, Benstead, \& Wang, 2021). Walaupun secara garis besar semua pasangan calon memiliki latar belakang yang mumpuni baik dari mantan sekretaris daerah, dan juga petahana.

Permasalahan yang unik adalah salah satu pasangan calon nomor dua merupakan putri keempat dari Wakil Presiden Ma'ruf Amin yaitu Siti Nurazizah yang juga sekaligus Wasekjen Partai Demokrat. Statusnya secara tidak langsung memberikan keistimewaan atau nilai lebih tersendiri (Cassan \& Vandewalle, 2021). Polarisasi isu dinasti politik menjadi sangat kental dalam Pilkada Tangerang Selatan karena melibatkan elit politik yang pada saat bersamaan menduduki jabatan penting di pemerintahan pusat. Sebagaimana yang dihadapi di Pilkada Kota Solo, penggunaan media sosial yang massif mempermudah penyebaran isu-isu dinasti dan identitas (Prihatini, 2020). Salah satunya identitas latar belakang yang melibatkan Menteri Pertahanan Prabowo Subianto dan Wakil Presiden Republik Indonesia.

Fenomena tersebut disebabkan oleh kuatnya pengaruh elit politik yang secara tidak langsung menghilangkan makna pelaksanaan demokrasi yang sesungguhnya. Keterpilihan dalam masyarakat disinyalir merupakan akibat dari kecenderungan pasangan calon yang lahir dari keluarga elit politik yang kuat secara finansial dan juga kendaraan politik (Haliim \& Hakim, 2020). Iklim politik berubah yang secara teoritis harus dijalankan secara meritokrasi diamputasi oleh dinasti politik yang terus menggurita (Gunanto, 2020). Kerabat pejabat publik berlomba-lomba untuk mencalonkan diri yang juga dalam jangka panjang berpengaruh terhadap partisipasi politik di masyarakat. Paradigma yang terbentuk adalah 
yang dapat menjadi pemimpin hanyalah yang kuat secara finansial dan kuat secara backingan.

Selain isu elit di belakang pasangan calon tersebut, berdasarkan catatan dari media, terdapat isu lain terhadap pasangan nomor urut satu Muhammad-Rahayu Saraswati Djojohadikusumo. Bentuk isu tersebut terkonfrontasi dalam wujud spanduk yang bertuliskan fitnah dengan frasa "korupsi lobster" dan kata "domba" yang cenderung pada unsur agama. Isu korupsi tersebut dimunculkan karena berhubungan dengan kasus korupsi. Wacana korupsi ini sengaja digulirkan sebagai upaya untuk memanipulasi pilihan massa terhadap pasangan calon ini sehingga secara tidak langsung mengancam elektabilitasnya, apalagi secara latar belakang pasangan ini adalah incumbent (Dulani, Rakner, Benstead, \& Wang, 2021). Permainan isu korupsi yang mengarah pada tuduhan terhadap salah satu pasangan calon mengindikasikan bahwa kasus korupsi yang juga dituduhkan kepada petahana (paslon nomor tiga) di pilkada ini menjadi bola panas yang digunakan untuk menjatuhkan lawan (Hambali, 2020). Antara pasangan calon dengan simpatisannya berusaha mencari isu yang menarik untuk dimainkan di publik karena pada dasarnya beberapa dari kandidat merupakan "pemain lama" di jajaran pemerintahan Tangerang Selatan. Upaya-upaya tersebut tersebar dengan massif melalui media sosial yang dilakukan oleh oknum-oknum yang memiliki kepentingan politik untuk menurunkan elektabilitas baik melalui isu dinasti politik dan berbagai isu lain yang dianggap dapat berhasil.

\section{SIMPULAN}

Dari berbagai contoh penggunaan politik identitas dan isu dinasti politik di beberapa daerah yang ada, terlihat bahwa problem identitas dan kuatnya dinasti politik masih menjadi masalah yang serius dan harus dihadapi oleh seluruh masyarakat Indonesia. Peluang untuk terpecah belahnya masyarakat akibat dari adanya politik identitas menjadi suatu realitas yang sulit untuk dihadapi saat ini. Pola isu yang digulirkan adalah berkaitan dengan hubungan kekerabatan dengan elit politik, identitas agama, kampanye hitam, hoax dan ujaran kebencian yang paling banyak muncul dengan strategi yang beragam. Isu politik identitas dan dinasti politik masih menjadi hal yang mengakar dalam setiap pergelaran politik tanah air sampai dengan saat ini. Masyarakat Indonesia harus membangun budaya baru tanpa politik identitas. Hal ini berfungsi agar masyarakat tidak terpecah belah dan sila Persatuan Indonesia dalam Pancasila dapat terwujud.

\section{DAFTAR RUJUKAN}

Aida, N. R. (2020). Berikut Daftar 270 Daerah yang Gelar Pilkada Serentak 9 Desember 2020. Diakses dari https://www.kompas. com/tren/read/2020/12/05/193100165/ berikut-daftar-270-daerah-yang-gelarPilkada-serentak-9-desember-2020?page=all

Anam, H. F. (2019). Politik Identitas Islam dan Pengaruhnya Terhadap Demokrasi di Indonesia Pendahuluan Politik Identitas dan Demokrasi: Kerangka Teoritis. Jurnal Pemikiran Politik Islam, 2(2), 181-188.

Arbi, I. A. (2020). Profil Calon Wali KotaWakil Wali Kota Tangerang Selatan, 3 Kandidat Terafiliasi Elite Politik. Diakses dari https://megapolitan.kompas.com/ $\mathrm{read} / 2020 / 12 / 09 / 09045341 /$ profil-calonwali-kota-wakil-wali-kota-Tangerang Selatan-3-kandidat-terafiliasi?page $=$ all

Ardipandanto, A. (2020). Dampak Politik Identitas Pada Pilpres 2019: Perspektif Populisme. Jurnal Politica Dinamika Masalah Politik dalam Negeri dan Hubungan Internasional, 11(1), 43-63.

Ayu, D. (2020). Dinamika Politik Identitas di Indonesia. Diakses dari http://rdk. fidkom.uinjkt.ac.id/index.php/2020/12/13/ dinamika-politik-identitas-di-indonesia/

Badan Penelitian dan Pengembangan Hukum dan HAM. (2020). Pilkada Serentak 2020 Masih diliputi Isu Politik Identitas dan SARA. Diakses dari https://www. balitbangham.go.id/detailpost/Pilkadaserentak-2020-masih-diliputi-isu-politikidentitas-dan-sara

Bayu, D. J. (2020). Berjayanya Dinasti Politik di Pilkada 2020. Diakses dari https://katadata.co.id/ariayudhistira/ infografik $/ 5 \mathrm{fd} 84 \mathrm{ceba} 55 \mathrm{cb} /$ berjayanyadinasti-politik-di-pilkada-2020

Cassan, G., \& Vandewalle, L. (2021). Identities and public policies: Unexpected effects of political reservations for women in India. World Development, 143, 105408.

Dauly, S. M., Kusmanto, H., \& Kadir, A. (2019). Politik Identitas Pada Pemilihan Gubernur 
Sumatera Utara tahun 2018. Jurnal Administrasi Publik: Public Administration Journal, 9(1), 51-59.

Dhani, F. W. (2019). Komunikasi Politik Berbasis Politik Identitas Dalam Kampanye Pilkada. Metacommunication: Journal of Communication Studies, 4(1), 143-153.

Drozdzewski, D., \& Matusz, P. (2021). Operationalising memory and identity politics to influence public opinion of refugees: A snapshot from Poland. Political Geography, 86, 102366.

Dulani, B., Rakner, L., Benstead, L., \& Wang, V. (2021). Do women face a different standard? The interplay of gender and corruption in the 2014 presidential elections in Malawi. Women's Studies International Forum, 88, 102501.

Effendi, W. R. (2018). Dinasti Politik Dalam Pemerintahan Lokal Studi Kasus Dinasti Kota Banten. Jurnal Trias Politika, 2(2), 233-243

Faridiany, M., Kusmanto, H., \& Warjio, W. (2019). Politik Identitas dalam Iklan Politik pada Pemilihan Kepala Daerah Sumatera Utara 2018. Jurnal Pendidikan Ilmu-Ilmu Sosial, 11(1), 113-123

Farisa, F. C. (2020). Ini Alasan Pemerintah Tak Mau Tunda Pilkada hingga Covid-19 Berakhir Diakses dari https://nasional. kompas.com/read/2020/05/29/07092271/ ini-alasan-pemerintah-tak-mau-tundaPilkada-hingga-covid-19-berakhir?page=all

Gandeng UAS, Kubu Bobby Tuding Akhyar Politik Identitas. (2021). Diakses dari https:/www.kba.one/news/gandenguas-kubu-bobby-tuding-akhyar-politik identitas/index.html

Gunanto, D. (2020). Tinjauan Kritis Politik Dinasti di Indonesia. Sawala: Jurnal Administrasi Negara, 8(2), 177-191.

Haliim, W., \& Hakim, A. I. (2020). Dinasti Politik: Basis Politik dan Kepuasan Publik. Jurnal Politik Profetik, 8(2), 258-268.

Hambali. (2020). Isu Korupsi di Pilkada Tangerang Selatan, Pengamat: Untungkan Calon Tanpa Beban Masa Lalu. Diakses dari https:// metro.sindonews.com/read/190668/171/ isu-korupsi-di-Pilkada-Tangerang Selatanpengamat-untungkan-calon-tanpa-bebanmasa-lalu-1602195014

Hornsey, M. J., Finlayson, M., Chatwood, G., \&
Begeny, C. T. (2020). Donald Trump and vaccination: The effect of political identity, conspiracist ideation and presidential tweets on vaccine hesitancy. Journal of Experimental Social Psychology, 8, 103947. Ichsan, A. P., Bachri, S., Riza, M., Hasanuddin, U., \& Hasanuddin, U. (2020). The Regulationof Independent Candidates in Organizing Regional Head Elections in Indonesia: A literature Review. Systematic Reviews in Pharmacy, 11(5), 896-901.

Jung, J., \& Mittal, V. (2020). Political Identity and the Consumer Journey: A Research Review. Journal of Retailing, 96(1), 55-73.

Kartika, M. (2020). Bawaslu: Politik Identitas Muncul di Pilkada 2020. Diakses dari https:// www.republika.co.id/berita/qkc9wf396/ bawaslu-politik-identitas-muncul-diPilkada-2020

Katzenstein, P. J. (1996). The Culture of National Security: Norms and Identity in World Politics. Columbia University Press.

Kurniawan. (2020). Kampanye Pilkada Solo 2020: Bajo dan Tim Pemenangan Langsung Gas Pol Blusukan Door to Door. Diakses dari https://www.solopos. com/kampanye-Pilkada-solo-2020-bajodan-tim-pemenangan-langsung-gas-polblusukan-door-to-door-1083492

Lerang, D. (2020). Panik, Kampanye Hitam Ben-Ujang Disebut Boneka. Diakses dari https:///palangka-raya/panik-kampanyehitam-ben-ujang-disebut-boneka

Lestari, D. (2019). Pilkada DKI Jakarta 2017: Dinamika Politik Identitas di Indonesia. Simulacra: Jurnal Sosiologi, 2(1), 31-41.

Mahpudin. (2019). Demokrasi dan Kabangkitan Politik Identitas: Refleski Perjalanan Demokrasi Indonesia Pasca. International Journal of Demos, 1(1), 1-18.

Marisa, H., Pornauli, A., Indra, A., \& Aurora, A. (2020). The Regional Head Elections (Pilkada) 2020 During Covid-19 Pandemic: A Projection. JOELS: Journal of Election and Leadership, 1(2), 64-68.

Mulang, I. (2020). 26 September-5 Desember 2020 Masa Kampanye Pilgub Kalteng. Diakses dari https://mediacenter.palangkaraya. go.id/26-september-5-desember-2020masa-kampanye-pilgub-kalteng/

Nata, D. (2021). Pilkada Kalteng Rentan Isu Sara, Provokasi dan Kampanye Hitam 
Via Medsos. Diakses dari https://rri. co.id/palangkaraya/Pilkada-serentakpolitik/909807/Pilkada-kalteng-rentanisu-sara-provokasi-dan-kampanyehitam-via-medsos? utm source=terbaru widget\&utm_medium=internal_link\&utm_ campaign $=$ General Campaign

Pamungkas, C., \& Triindriasari, D. (2018). Ketahanan Orang Asli Papua the 2018 Papua Gubernatorial Election: Politics of Identity, Governance, and Life Forces of Papuan Natives. Jurnal Masyarakat dan Budaya, 20(3), 391-406.

Prabowo, D. (2020). Catat, Sederet Larangan dan Sanksi Saat Kampanye Pilkada 2020. Diakses dari https://nasional.kompas.com/ read/2020/09/24/15362571/catat-sederetlarangan-dan-sanksi-saat-kampanyePilkada-2020? page =all

Pradita, S., \& Sicca. (2020). Pilkada 2020 di Mata Media Asing, Dinasti Politik Jokowi Jadi Sorotan. Diakses dari https://www.kompas. com $/ \mathrm{global} / \mathrm{read} / 2020 / 12 / 09 / 214234870 /$ Pilkada-2020-di-mata-media-asing-dinastipolitik-jokowi-jadi-sorotan?page=all

Prihatini, E. S. (2018). Indonesian young voters: Political knowledge and electing women into parliament. Women's Studies International Forum, 70, 46-52.

Ristyawati, A. (2020). Efektivitas Pelaksanaan Pilkada Serentak 2020 Pada Masa Pandemi Darurat Covid-19 di Indonesia. Crepido, 2(2), 85-96.

Sandi, J. R. A., \&. S. (2020). Fenomena Pengawasan Pemilihan Kepala Daerah Di Kalimantan Tengah Masa Pandemi Covid-19. Jurnal
Politik Pemerintahan Dharma Praja, 13(1), 1-13.

Slamet, A. (2019). Identitas Politik Dalam Komunikasi Politik Calon Gubernur Jawa Barat Tahun 2018. Linimasa: Jurnal Ilmu Komunikasi, 2(1), 20-30

Suryatwan, A. (2020). Dinasti Politik Pada Kepemimpinan Presiden Jokowi Akibat Kontestasi Politik Lokal Gibran-Bobby. Journal Publicuho, 3(3), 289-294.

Trisnawati, S. (2020). Isu SARA Mulai Dihembuskan Jelang Pilkada. Rri.Co.Id. Retrieved from https://rri.co.id/palangkaraya/Pilkada-serentakpolitik/879105/isu-sara-mulai-dihembuskanjelang-Pilkada?utm_source $=$ terbaru widget\&utm_medium=internal_link\&utm campaign $=\overline{\text { General Campaign }}$

Vakil, S. (2018). Equity in Computer Science Education. Harvard Educational Review, 88(1), 26-53.

Wartika. (2020). Politik Identitas: Ancaman dalam Pilkada 2020. Diakses dari https:// indonews.id/artikel/26718/Politik-Identitas-Ancaman-dalam-Pilkada-2020/

Wibowo, E. A. (2020). Biaya Kampanye Gibran Habis Rp3,2 Miliar, Rivalnya Bagyo Cuma Rp110 Juta. Dikases dari https://nasional. tempo.co/read/1412419/biaya-kampanyegibran-habis-rp-32-miliar-rivalnya-bagyocuma-rp-110-juta

Zamani, L. (2020). KPU Tetapkan Gibran-Teguh dan Bajo sebagai Calon Wali Kota Solo. Diakses dari https://regional.kompas.com/ $\mathrm{read} / 2020 / 09 / 23 / 14155421 / \mathrm{kpu}$-tetapkangibran-teguh-dan-bajo-sebagai-calonwali-kota-solo 